\title{
ANALISIS KESULITAN BELAJAR SISWA PADA MATERI POKOK SISTEM INDRA MANUSIA (PENGLIHATAN, PENDENGARAN DAN PENGECAP) DI KELAS XI IPA MAN 1 STABAT
}

\section{ANALYSIS OF STUDENTS LEARNING DIFFICULTIES IN THE SUBJECT MATTERIALS OF HUMAN SENSORY SYSTEMS (SIGHT, HEARING AND TASTE) IN CLASS XI IPA OF MAN 1 STABAT}

\author{
Silvia Adriani ${ }^{*}$, Lazuardi \\ Program Studi Pendidikan Biologi, Universitas Negeri Medan, \\ Jl. Willem Iskandar Psr V Medan, Indonesia, kode pos 20221 \\ *email: svia700@gmail.com
}

\section{ABSTRAK}

Penelitian ini bertujuan untuk mengetahui kesulitan belajar siswa dari pengamatan percobaan indra manusia, aspek kognitif dan indikator pembelajaran serta faktor penyebab kesulitan belajar siswa di kelas XI IPA MAN 1 Stabat Tahun Pembelajaran 2015/2016. Desain penelitian yang digunakan yaitu deskriptif kuantitatif. Sampel diambil secara total sampling dengan jumlah 71 siswa. Teknik pengumpulan data dengan menggunakan tes pengamatan, tes diagnostik dan angket. Hasil penelitian menunjukkan persentase kesulitan belajar siswa dari yang tertinggi sampai terendah pada aspek kognitif yaitu C5, C6, C3, C4, C2 dan C1 sebesar 70,43\%, 53,06\%, 51,17\%, 47,09\%, 44,72\%, dan 34,51\%. Persentase kesulitan belajar siswa berdasarkan indikator pada materi sistem indra manusia yaitu indikator (1) sebesar 65,26\% dengan kategori sangat tinggi, indikator (2) sebesar 45,54\% dengan kategori tinggi, indikator (3) sebesar 43,98\% dengan kategori tinggi dan indikator (4) sebesar 53,93\% dengan kategori sangat tinggi. Faktor internal dan eksternal penyebab kesulitan belajar dari persentase kesulitan belajar tertinggi sampai terendah adalah materi pelajaran (61,40\%), lingkungan sekolah (61,26\%), media pembelajaran (54,66\%), inteligensi $(45,07 \%)$, motivasi $(43,48 \%)$, orang tua $(42,69 \%)$, lingkungan sekitar $(41,81 \%)$, psikiatik $(41,19 \%)$, guru $(41,10 \%)$, minat $(39,17 \%)$ dan kesehatan $(38,99 \%)$.

Kata Kunci: Aspek Kognitif, Indikator Pembelajaran, Kesulitan Belajar, Sistem Indra Manusia

\section{ABSTRACT}

This study aims to determine the students' learning difficulties from the experimental observations of human sensory, cognitive and learning indicators and factors that cause the learning difficulties in class XI of Science at MAN 1 Stabat at the year of learning 2015/2016. The study used descriptive quantitative design. Samples were taken by total sampling with 71 students. The technique of data collection used observation tests, diagnostic tests and questionnaires. The results show that the percentage of the students' learning difficulties from the highest to the lowest on cognitive aspects, they are C5, C6, C3, C4, C2 and C1 for amount 70.43\%, 53.06\%, 51.17\%, 47.09\%, 44, 72\% and 34.51\%. The Percentage of students' learning difficulties based on the indicators in the material of human sensory system are indicator (1) amount $65.26 \%$ categorized as very high, the indicator ( 2 ) amount $45.54 \%$ categorized as high, the indicator ( 3 ) amount $43.98 \%$ categorized as high and the indicator (4) of 53.93\% categorized as very high. Internal and external factors that cause the learning difficulties of learning difficulties highest to lowest percentage are the subject matter (61.40\%), the school environment (61.26\%), instructional media (54.66\%), intelligence (45.07\%), motivation (43.48\%), parents (42.69\%), the environment (41.81\%), psikiatik (41.19\%), teachers $(41.10 \%)$, interest $(39.17 \%)$ and health (38.99\%).

Keywords: Cognitive Aspects, Human Sensory Systems, Learning Difficulties, , Learning Indicators,

\section{PENDAHULUAN}

Pada umumnya, kesulitan belajar siswa merupakan suatu kondisi belajar yang ditandai dengan adanya hambatan dalam kegiatan pembelajaran sehingga memerlukan usaha lebih giat lagi untuk dapat mengatasinya. Kesulitan belajar siswa dapat dilihat dari hasil belajar yang dicapainya. Aktifitas belajar siswa tidak selamanya berjalan lancar (Syah, 2011). 
Kesulitan belajar tidak hanya disebabkan karena intelegensi yang rendah, juga disebabkan oleh faktor-faktor non intelegensi yaitu faktor internal dan faktor eksternal. Faktor internal dikelompokkan menjadi tiga faktor, yaitu: faktor jasmaniah, faktor psikologis dan faktor kelelahan. Sedangkan faktor ekstern dikelompokkan menjadi faktor keluarga, faktor sekolah dan faktor masyarakat (Slameto, 2010). Faktor eksternal merupakan faktor yang paling mempengaruhi kesulitan belajar siswa (Raharjo dan Ahyani, 2011).

Dari hasil observasi di MAN 1 Stabat, peneliti melihat terdapat siswa yang bermain-main atau berbincang-bincang dengan temannya pada saat guru sedang menjelaskan di depan kelas, mengerjakan tugas mata pelajaran lain selain biologi saat di dalam kelas, dan siswa sering tidak membawa buku pegangan tambahan mata pelajaran, karena di sekolah tersebut masih menggunakan LKS. Peneliti juga melihat bahwa kurangnya fasilitas belajar yang mendukung di sekolah, penerapan model dan metode pembelajaran yang tidak sesuai dan kurangnya motivasi siswa untuk belajar menjadi penyebab kesulitan belajar siswa.

Dalam konteks mata pelajaran Biologi, sebagian peserta didik menganggap adalah mata pelajaran yang sulit, meskipun beberapa siswa menyenanginya (Ngadi, 2003). Hasil wawancara dengan siswa juga mendapatkan hasil yang sama, siswa merasa pelajaran biologi banyak menggunakan istilah latin terutama pelajaran sistem indra manusia yang membuat mereka kesulitan untuk mengingat.

Kurniadi (2015) menjelaskan lebih lanjut, pembelajaran di dalam kelas pun yang hanya menggunakan metode konvensional (ceramah) yang tidak dapat menggali kemampuan berpikir siswa. Padahal materi sistem indra manusia ini membutuhkan pemahaman dan proses bernalar yang baik dalam memecahkan permasalahan yang terjadi pada tubuh manusia melalui pembelajaran. Sebaiknya dalam pembelajaran IPA termasuk Biologi pada materi sistem indra manusia dilaksanakan sesuai dengan hakikat IPA, yaitu menekankan pada pemberian pengalaman langsung untuk mengembangkan kompetensi siswa. Siswa tidak hanya mempelajari kumpulan pengetahuan yang berupa fakta, konsep, atau prinsip, tetapi mempelajarinya melalui proses penemuan dan penelitian.

Mempelajari Biologi khususnya pada sistem indra manusia, materi tersebut berisi konsep-konsep yang bersifat abstrak, terutama mengenai proses yang terjadi di dalam tubuh, fungsi-fungsi organ dalam/alat indra, banyaknya kelainan-kelainan pada setiap indra manusia yang menyebabkan siswa menerka atau berasumsi saja tanpa mengamati secara langsung bagaimana proses dari sistem indra itu terjadi sehingga menyebabkan miskonsepsi pada siswa.

\section{METODE PENELITIAN}

Penelitian dilakukan di MAN 1 Stabat Kabupaten Langkat pada bulan April - Juni 2016. Jenis penelitian yang digunakan adalah penelitian deskriptif kuantitatif, yang bertujuan untuk mengorganisasi dan mengolah data angka-angka hasil belajar siswa dan hasil angket yang diberi penskoran, agar dapat memberikan gambaran secara teratur, singkat, dan jelas mengenai suatu keadaan sehingga dapat ditarik pengertian atau makna tertentu.

Teknik pengumpulan data penelitian menggunakan tes pengamatan, tes diagnostik dan angket. Analisis data yang digunakan dalam penelitian ini dengan menggunakan deskriptif kuantitatif.

\section{HASIL PENELITIAN}

Dari pengamatan percobaan, tes diagnostik dan angket kepada responden mengenai materi tentang sistem indra manusia (indra penglihatan, indra pendengaran dan indra pengecap) bahwa pengamatan percobaan yang merupakan tes awal penelitian kepada siswa (6 praktikan) dalam keadaan normal/sehat. Pada pengamatan pada indra penglihatan (mata) rata-rata menunjukkan perbedaan jarak hilangnya tanda $X$ pada waktu pengamatan hanya sedikit. Bayangan suatu benda tidak nampak pada jarak tertentu, karena pembiasan cahaya dari suatu benda tersebut jatuh di bagian bintik buta pada retina. Pada pengamatan indra pendengaran (telinga) pemeriksaan ketajaman pendengaran dapat dilakukan dengan tes rinne, tes weber dan tes schwabach, dari 6 praktikan (siswa) hanya 3-4 praktikan yang dapat mendengar getaran garputala dengan baik. Pada pengamatan indra pengecap (lidah) siswa memiliki kondisi lidah dalam keadaan normal, dimana ke 6 siswa merasakan rasa yang sama tepat pada bagian lidah yang dapat merasakan manis, asam, asin dan pahit.

Pada tes diagnostik, dari 71 siswa yang tuntas dan mencapai KKM 80 hanya 6 orang, selebihnya siswa dikatakan tidak tuntas pada materi sistem indra manusia. Nilai rata-rata yang diperoleh siswa adalah 50,42. Tes diagnostik dianalisis berdasarkan aspek kognitif berupa C1 sampai C6 dan berdasarkan indikator pembelajaran. 
Hasil angket menujukkan bahwa faktor yang berpengaruh terhadap kesulitan belajar berasal dari faktor eksternal yaitu faktor materi pelajaran dan lingkungan sekolah. Faktor yang cukup mempengaruhi terhadap kesulitan belajar dari faktor internal maupun faktor eksternal adalah psikiatik, inteligensi, motivasi, orang tua, guru, media pembelajaran dan lingkungan sekitar. Sedangkan faktor kesehatan dan minat kurang mempengaruhi kesulitan belajar siswa dalam mempelajari materi sistem indra manusia.

\section{PEMBAHASAN}

Penelitian dengan menggunakan tes diagnostik menunjukkan bahwa siswa mengalami kesulitan belajar dalam mempelajari materi sistem indra manusia (indra penglihatan, pendengaran, dan pengecap) yang terlihat dari banyaknya jumlah siswa yang tidak tuntas pada materi tersebut baik dari aspek kognitif dan indikator pembelajaran di kelas XI IPA MAN 1 Stabat.

Kesulitan belajar siswa dari aspek kognitif memiliki tingkat kesulitan belajar dalam kategori sedang, tinggi dan sangat tinggi. Kesulitan belajar siswa pada aspek pengetahuan (C1) tergolong dalam kategori sedang sebesar 34,15\%, dapat diketahui bahwa siswa memiliki kemampuan dasar yang cukup tentang struktur dari sistem indra manusia. Pada aspek pemahaman (C2) tergolong dalam kategori tinggi sebesar $44,72 \%$, hasil jawaban siswa masih kurang terutama dalam memahami bagian-bagian indra telinga dan kelainan pada indra mata. Pada aspek penerapan (C3) tergolong dalam kategori sangat tinggi sebesar 51,17\%, kesulitan dalam menjawab soal pada aspek ini disebabkan siswa tidak benar-benar menerapkan pengetahuannya pada materi sistem indra manusia secara mendalam. Pada aspek analisis (C4) tergolong dalam kategori sangat tinggi sebesar $47,09 \%$, sebagian besar siswa masih belum dapat menganalisis dengan baik pengetahuan dasar yang dikatahuinya tentang sistem indra manusia. Pada aspek sintesis (C5) tergolong dalam kategori sangat tinggi sebesar $70,43 \%$, dengan jumlah siswa yang menjawab benar semakin sedikit disebabkan tingkat kemampuan siswa dalam menjawab soal pada aspek ini masih rendah. Pada aspek kreasi (C6) tergolong dalam kategori sangat tinggi sebesar 53,06\%. Pada aspek ini siswa masih belum memahami dengan baik penyakit/kelainan yang terjadi pada indra mata, indra telinga maupun indra lidah.

Tabel 1. Distribusi Kesulitan Belajar Siswa Berdasarkan Aspek Kognitif

\begin{tabular}{ccccc}
\hline No. & Aspek Kognitif & $\begin{array}{c}\text { Persentase } \\
\text { Penguasaan Siswa (\%) }\end{array}$ & $\begin{array}{c}\text { Kesulitan Belajar } \\
\text { Siswa (\%) }\end{array}$ & $\begin{array}{c}\text { Kategori } \\
\text { Kesulitan }\end{array}$ \\
\hline 1. & C1 & 65,49 & 34,51 & Sedang \\
2. & C2 & 55,28 & 44,72 & Tinggi \\
3. & C3 & 49,76 & 51,17 & Sangat Tinggi \\
4. & C4 & 52,91 & 47,09 & Sangat Tinggi \\
5. & C5 & 29,57 & 70,43 & Sangat Tinggi \\
6. & C6 & 46,94 & 53,06 & Sangat Tinggi \\
\hline
\end{tabular}

Kesulitan belajar siswa pada materi sistem indra manusia dari aspek indikator pembelajaran memiliki tingkat kesulitan belajar dalam kategori tinggi dan sangat tinggi. Mengidentifikasi struktur, fungsi, dan proses sistem indra manusia (Indikator 1) berada dalam kategori sangat tinggi dengan persentase kesulitan paling banyak dibandingkan indikator-indikator lainnya sebesar 65,26\%. Hal ini menunjukkan bahwa siswa belum memahami bagian-bagian, fungsi serta proses yang terjadi pada indra manusia yaitu pada mata, telinga dan lidah. Mengkaitkan struktur, fungsi, dan proses sistem indra manusia (Indikator 2) dalam kategori tinggi sebesar $45,54 \%$. Siswa masih sulit untuk mengingat antara struktur dan fungsi indra dengan baik, meskipun sebagian siswa hanya mengingat antara struktur dan fungsi yang umum mereka pelajari. Menjelaskan struktur, fungsi, dan proses sistem indra manusia (Indikator 3) dalam kategori tinggi sebesar 43,98\%. Mendeskripsikan gejala, penyebab, dan pencegahan/ pengobatan pada kelainan yang terjadi pada sistem indra manusia (Indikator 4) dalam kategori sangat tinggi sebesar 53,93\%, disebabkan banyaknya kelainan/penyakit yang terjadi pada sistem indra manusia terutama pada mata, telinga dan lidah.

Berdasarkan hasil tes diagnostik masih banyak siswa yang tidak tuntas sehingga perlu dilihat faktor yang mempengaruhi kesulitan belajar siswa. Angket diberikan kepada setiap siswa untuk melihat faktor-faktor yang menyebabkan siswa mengalami kesulitan belajar sesuai dengan indikator-indikator kesulitan belajar yang diukur.

Faktor internal cukup mempengaruhi kesulitan belajar siswa. Kategori kurang berpengaruh terdapat pada indikator minat dan kesehatan yaitu 
sebesar 39,17\% dan 38,99\%. Sedangkan untuk kategori cukup berpengaruh terdapat pada indikator inteligensi, motivasi, dan psikiatik yaitu sebesar $45,07 \%, 43,48 \%$, dan $41,19 \%$. Selain faktor internal, faktor eksternal juga banyak mempengaruhi kesulitan belajar siswa. Untuk kategori cukup berpengaruh terdapat pada indikator media pembelajaran, orang tua, lingkungan sekitar, dan guru yaitu sebesar 54,66\%, 42,69\%, 41,81\%, dan $41,10 \%$. Sedangkan untuk kategori berpengaruh terdapat pada indikator materi pelajaran dan lingkungan sekolah sebesar $61,40 \%$ dan $61,26 \%$.

Tabel 2. Distribusi Kesulitan Belajar Siswa Berdasarkan IndikatorPembelajaran Materi Sistem Indra Manusia

\begin{tabular}{clccc}
\hline No. & \multicolumn{1}{c}{ Indikator Pembelajaran } & $\begin{array}{c}\text { Penguasaan } \\
\text { Siswa (\%) }\end{array}$ & $\begin{array}{c}\text { Kesulitan } \\
\text { Belajar (\%) }\end{array}$ & $\begin{array}{c}\text { Kategori } \\
\text { Kesulitan }\end{array}$ \\
\hline 1. & $\begin{array}{l}\text { Mengidentifikasi struktur, fungsi, dan } \\
\text { proses sistem indra manusia }\end{array}$ & $34,74 \%$ & $65,26 \%$ & Sangat Tinggi \\
2. $\quad \begin{array}{l}\text { Mengkaitkan struktur, fungsi, dan proses } \\
\text { sistem indra manusia }\end{array}$ & $54,46 \%$ & $45,54 \%$ & Tinggi \\
3. $\quad \begin{array}{l}\text { Menjelaskan struktur, fungsi, dan proses } \\
\text { sistem indra manusia } \\
\text { Mendeskripsikan gejala, penyebab, dan } \\
\text { pencegahan/ pengobatan pada kelainan } \\
\text { yang terjadi pada sistem indra manusia }\end{array}$ & $56,02 \%$ & $43,98 \%$ & Sangat Tinggi \\
\hline
\end{tabular}

Faktor kesehatan kurang mempengaruhi kesulitan belajar siswa dalam mempelajari materi sistem indra manusia karena siswa memiliki kesehatan yang cukup baik, mereka dapat melihat dan mendengar dengan jelas ketika guru biologi menerangkan materi sistem indra manusia walaupun sedikit dari siswa yang menyatakan tidak dapat melihat dengan jelas di papan tulis dan pada saat di kelas siswa.

Faktor psikiatik merupakan faktor yang cukup mempengaruhi kesulitan belajar siswa kelas XI IPA MAN 1 Stabat, hal itu terlihat dari sikap-sikap siswa yang tidak baik pada saat pembelajaran berlangsung. Sebagian siswa kadang-kadang tidak dapat berkonsentrasi pada saat guru menjelaskan materi, artinya mereka tidak dapat memusatkan perhatian terhadap penjelasan guru, sehingga hal tersebut dapat menyebabkan siswa sulit memahami materi tersebut. Sementara Slameto (2010), mengatakan untuk dapat menjamin hasil belajar yang baik, maka siswa harus mempunyai perhatian terhadap bahan yang dipelajarinya, jika bahan pelajaran tidak menjadi perhatian siswa atau menarik, maka timbullah kebosanan, sehingga ia tidak lagi suka belajar.

Faktor inteligensi juga cukup berpengaruh terhadap kesulitan belajar siswa, karena menurut Djamarah (2011), orang yang inteligensinya rendah, cenderung mengalami kesukaran dalam belajar, lambat berpikir sehingga prestasi belajarnya pun rendah.

Faktor minat kurang berpengaruh terhadap kesulitan belajar siswa. Siswa rajin mengerjakan soal-soal latihan yang diberikan oleh guru. Selain itu, catatan buku biologi siswa rapi karena selalu diperiksa oleh guru setiap kali pembelajaran. Minat dari siswa untuk belajar materi sistem indra manusia ini berjalan dengan baik walaupun kadang-kadang sebagian siswa menyatakan merasa bosan saat proses pembelajaran berlangsung.

Faktor motivasi merupakan faktor yang paling cukup berpengaruh. Menurut Dalyono (2011), kuat lemahnya motivasi belajar seseorang turut mempengaruhi keberhasilan belajar. Karena itu motivasi belajar perlu diusahakan, terutama yang berasal dari dalam diri (motivasi instrinsik) dengan cara senantiasa memikirkan masa depan yang penuh tantangan dan harus dihadapi untuk mencapai citacita dapat dicapai dengan belajar.

Faktor orang tua juga merupakan faktor yang cukup berpengaruh terhadap kesulitan belajar. Hal yang paling sering terjadi adalah ketika pulang sekolah siswa harus membantu orang tua sehingga siswa tidak punya waktu yang banyak untuk mengulangi kembali pelajaran di rumah. Hal tersebut menyebabkan siswa mengalami kesulitan belajar dalam mempelajari materi sistem indra manusia.

Faktor guru cukup berpengaruh terhadap kesulitan belajar, disebabkan oleh guru tidak dapat menjelaskan materi dengan baik dan menyenangkan serta saat pembelajaran guru kurang bervariasi menggunakan metode dalam mengajar materi sistem indra manusia, sehingga siswa merasa bosan dalam mempelajari materi tersebut. Sesuai penelitian oleh Ngadi (2003) bahwa guru terindikasi mengajarkan materi sebagai kumpulan teori konseptual daripada membangun kemampuan peserta didik dalam bernalar dan berpikir. 
Faktor lingkungan sekolah dilihat dari segi alokasi waktu, kondisi ruangan kelas, fasilitas dan letak sekolah tersebut. Siswa mengatakan bahwa ruangan kelas yang mereka tempati pengap dan kurang penerangan, sekolah juga tidak menyediakan fasilitas yang memadai, sehingga memperlambat proses belajar mengajar biologi meskipun waktu yang digunakan untuk materi sistem indra manusia sudah cukup. Letak sekolah yang dekat dengan jalan raya, sehingga terdengar jelas kebisingan yang dapat mengganggu konsentrasi belajar.

Materi pelajaran merupakan faktor ekstenal dengan persentase kesulitan belajar tertinggi. Dari hasil tes diagnostik telah menunjukkan bahwa siswa mengalami kesulitan belajar yang tinggi pada indikator mengidentifikasi struktur, fungsi, dan proses sistem indra manusia. Pada tes diagnostik diketahui bahwa siswa yang menjawab soal dengan tuntas hanya 6 orang dari 71 orang siswa di kelas XI $I P A_{1}$ dan XI IPA . Siswa sulit untuk mengingat bahasa latin dari setiap bagian-bagian penyusun dari indra manusia, fungsi dari setiap organ.
Faktor media pembelajaran merupakan faktor yang cukup berpengaruh disebabkan oleh siswa yang jarang menggunakan berbagai media untuk menambah pengetahuannya mengenai sistem indra manusia, mereka hanya mengandalkan satu buku LKS yang dibagikan dari sekolah. Selain minimnya fasilitas praktikum, laboratorium di sekolah MAN 1 Stabat juga masih pada tahap pembangunan sehingga jika ada materi yang mengharuskan untuk praktikum guru hanya menjelaskan saja atau dapat menggunakan alat dan bahan yang sederhana.

Faktor lingkungan masyarakat cukup berpengaruh terhadap kesulitan belajar. Hasil angket siswa menunjukkan bahwa mereka kadang-kadang tidak dapat memilih teman bergaul yang baik, sehingga waktu belajar mereka sering terganggu akibat pergaulan yang tidak baik. Pergaulan yang tidak baik menyebabkan mereka sulit mengatur waktu antara belajar dengan waktu bermain bersama teman.

Tabel 3.Kategori Faktor Penyebab Kesulitan Belajar

\begin{tabular}{lcc}
\hline Faktor Penyebab Kesulitan Belajar & Tingkat Kesulitan (\%) & Kategori \\
\hline \multicolumn{1}{c}{ A. Faktor Internal } & & Kurang Berpengaruh \\
\hline Kesehatan & $38,99 \%$ & Cukup Berpengaruh \\
Psikiatik & $41,19 \%$ & Cukup Berpengaruh \\
Inteligensi & $45,07 \%$ & Kurang Berpengaruh \\
Minat & $39,17 \%$ & Cukup Berpengaruh \\
Motivasi & $43,48 \%$ & \\
\hline B. Faktor Eksternal & & Cukup Berpengaruh \\
\hline Orang tua & $42,69 \%$ & Cukup Berpengaruh \\
Guru & $41,10 \%$ & Berpengaruh \\
Lingkungan Sekolah & $61,26 \%$ & Berpengaruh \\
Materi Pelajaran & $61,40 \%$ & Cukup Berpengaruh \\
Media Pembelajaran & $54,66 \%$ & Cukup Berpengaruh \\
Lingkungan Sekitar & $41,81 \%$ & \\
\hline
\end{tabular}

\section{KESIMPULAN}

Berdasarkan hasil penelitian dapat disimpulkan bahwa iswa kelas XI IPA MAN 1 Stabat mengalami kesulitan dalam belajar materi Sistem Indra Manusia dari persentase tertinggi sampai terendah pada aspek kognitif yaitu tingkat sintesis (C5) sebesar 70,43\%, kreasi (C6) sebesar 53,06\%, penerapan (C3) sebesar 51,17\%, analisis (C4) sebesar $47,09 \%$, pemahaman (C2) sebesar $44,72 \%$, dan pengetahuan (C1) sebesar $34,51 \%$. Siswa kelas XI IPA MAN 1 Stabat mengalami kesulitan dalam belajar materi Sistem Indra Manusia pada aspek indikator pembelajaran, yaitu mengidentifikasi struktur, fungsi, dan proses sistem indra manusia sebesar 65,26\%, mengkaitkan struktur, fungsi, dan proses sistem indra manusia sebesar 45,54\%, menjelaskan struktur, fungsi, dan proses sistem indra manusia sebesar 43,98\%, dan mendeskripsikan gejala, penyebab, serta pencegahan/pengobatan pada kelainan yang terjadi pada sistem indra manusia sebesar 53,93\%. Faktor penyebab kesulitan belajar siswa kelas XI IPA MAN 1 Stabat pada materi Sistem Indra Manusia untuk kategori berpengaruh adalah pada faktor materi pelajaran dan lingkungan sekolah, 
Halaman : 404- 409

kategori cukup berpengaruh terdapat pada faktor media pembelajaran, inteligensi, motivasi, orang tua, lingkungan sekitar, psikiatik dan guru, kategori kurang berpengaruh terdapat pada kategori minat dan kesehatan.

Penulis menyarankan bagi sekolah, agar menyediakan fasilitas yang lengkap untuk pembelajaran materi sistem indra manusia sehingga siswa lebih paham dalam belajar. Bagi guru, agar lebih meningkatkan kualitas mengajar di kelas sehingga menumbuhkan motivasi belajar siswa untuk mempelajari materi sistem indra manusia.

\section{DAFTAR PUSTAKA}

Djamarah, S.B., (2011), Psikologi Belajar. Penerbit Rineka Cipta, Jakarta.

Dalyono, M., (1995), Psikologi Pendidikan. Penerbit Rineka Cipta, Jakarta.

Kurniadi, A., (2015), Analisis Reasoning Skill Siswa pada Pembelajaran Biologi SMA. Prosiding Simposium Nasional Inovasi dan Pembelajaran Sains. Hal:237.

Ngadi, (2003), Diagnosis Kesulitan BelajarIPA (Sains) Peserta Didik SMP Negeri 3 Sumenep, 1(2): 1-9.

Raharjo, T., dan Ahyani, L.N., (2011), Identifikasi Kesulitan Belajar pada Anak Usia Dini, Jurnal Pendidikan, 1(1):1-9.

Slameto, (2010), Belajar dan Faktor-faktor yang Mempengaruhinya. Penerbit Rineka Cipta, Jakarta.

Syah, M., (2011), Psikologi Pendidikan dengan Pendekatan Baru. Penerbit PT. Remaja Rosdakarya, Bandung. 